\section{Africa and the wider world: creole communities in the Atlantic and Indian Oceans}

\author{
Malyn Newitt[1]
}

\begin{abstract}
Portuguese creoles were instrumental in bringing sub-Saharan Africa into the intercontinental systems of the Atlantic and Indian Ocean. In the Atlantic Islands a distinctive creole culture emerged, made up of Christian emigrants from Portugal, Jewish exiles and African slaves. These creole polities offered a base for coastal traders and became politically influential in Africa - in Angola creating their own mainland state. Connecting the African interior with the world economy was largely on African terms and the lack of technology transfer meant that the economic gap between Africa and the rest of the world inexorably widened. African slaves in Latin America adapted to a society already creolised, often through adroit forms of cultural appropriation and synthesis. In eastern Africa Portuguese worked within existing creolised Islamic networks but the passage of their Indiamen through the Atlantic created close links between the Indian Ocean and Atlantic commercial systems.
\end{abstract}

Keywords: Creolisation; globalisation; slave trade

África e o vasto mundo: comunidades crioulas nos Oceanos Atlântico e Índico

Resumo: Os crioulos portugueses foram fundamentais para integrar a África subsaariana aos sistemas intercontinentais do Oceano Atlântico e do Oceano Índico. Nas ilhas atlânticas emergiu uma cultura crioula distinta, composta por emigrantes cristãos vindos de Portugal, judeus exilados e escravos africanos. Essas políticas crioulas ofereceram uma base para comerciantes costeiros e se tornaram politicamente influentes na África - em Angola criando seu próprio país continental. Conectar o interior africano com a economia mundial foi, em grande medida, feita em termos africanos, mas a falta de transferência de tecnologia significou que o fosso econômico entre África e o resto do mundo aumentou inexoravelmente. Escravos africanos na América Latina adaptaram-se a uma sociedade já crioulizada, muitas vezes por meio de formas hábeis de apropriação e síntese cultural. $\mathrm{Na}$ África Oriental, o português trabalhou em já existentes redes islâmicas crioulizadas, mas a passagem de naus da carreira das Índias através do Atlântico criou vínculos estreitos entre os sistemas comerciais do Oceano Índico e do Atlântico.

Palavras-chave: Crioulização; globalização; tráfico de escravos 


\section{Understanding the history of Africa}

$\mathrm{F}$ or a long time there has been a prevailing narrative among historians and commentators on Africa that, when sub-Saharan Africa was incorporated into the global economy from the fifteenth century, it was on unequal terms which ensured that Africa would remain undeveloped. This narrative continues through the era of the slave trade into the short period of direct colonial control and on into the era of independence when the "unequal" relationships have only intensified with the spread of globalisation.

This narrative, which too often assigns to Africans the passive role of victim, has been challenged by a number of scholars who have pointed to African agency in commercial relations - and not least by Patrick Chabal who, in a number of books, has pointed out that African elites have always been in control of relations with outsiders and that so-called underdevelopment has been instrumentalised by the elites for their own advantage. ${ }^{2}$

Trade between Africa and the rest of the world was always extremely profitable for all those who took part and the key question becomes-how was the wealth generated in this way utilised. In Europe and the Americas the profits of African trade (including of course the slave trade) were invested in plantation agriculture, the production of agricultural surpluses and ultimately the process of industrialisation. But how were the profits of the trade utilised in Africa?

Two key factors have often been advanced to explain why Africa did not appear to benefit in the long run from this commerce-the intensification of warfare resulting from the slave trade and the haemorrhage of population. It is not the aim of this paper to address these issues directly but to re-examine the part played by Portuguese creoles, not as minor actors but as major participants in developments which determined Africa's relations with the Atlantic and Indian Ocean worlds. The study of creolization in all its different forms, challenges the binary approach to African history-the relentless opposition of colonialism and independence, black and white, slave and free, developed and underdeveloped, the West and the Rest, the New World and Old. African historians now need to shed this Manichean intellectual inheritance and to be more nuanced in their interpretations and in the questions they ask (Naro, Sansi-Roca and Treece, 2007, p. 1).

The study of globalisation is now a major academic industry. The term describes the way that finance and markets, the movement of populations, and the spread of cultures, religions and ideas have come to operate across the world. Although many of these features characterised the Mediterranean, Central Asian and Indian Ocean worlds from early times, the development of a truly global reach only occurred with the discovery of the Americas

${ }^{2}$ Notably in Chabal and Daloz (1999). This study is fundamental to any understanding of African history and contemporary affairs. 
and the rapid incorporation of the Atlantic world into a global system (see, for example, Hopkins, 2002).

That the Portuguese played a major role in creating this new phase of globalisation has long been recognised - their maritime explorations made a coherent understanding of the physical world possible for the first time, their maritime trade made Spanish silver reales and patacas a universal currency of exchange and their sponsorship of missions led to an unprecedented expansion of Christianity. Moreover, the Portuguese were instrumental in spreading food crops from one continent to another and in propounding ideas that later solidified into international law. Most important of all, it was the through the commercial and cultural channels established by the Portuguese that the first large-scale movement of peoples between the continents took place (see Russell-Wood, 1992).

To understand how Africa was affected by globalisation it is important to recognise that cultural hybridity is a feature of African history, even where no European or Islamic outsiders are involved. Africa has constantly seen migrations and the dominance established by one group over another. In Central Africa the conquests of the Karanga dynasties at the end of the fifteenth century and the Maravi at the end of the sixteenth involved the new ruling elites having to adjust to the customs and beliefs of the conquered, while the conquered had to observe the rituals of their overlords. These adaptations also involved intermarriage between conquerors and conquered. Alongside these conquests another form of state creation took place where a dominant individual or group acquired clients and, through natural procreation and the rewarding of clients with the distribution of slaves (often women), plunder or the import of prestige goods, established not only a new state but sometimes a new ethnic identity. It was this recurring pattern of political and social change that allowed Islamic and Portuguese outsiders to insert themselves so easily into African society and begin their own process of creolization. And it was largely through the creolized populations that emerged through the meeting of Islamic and European outsiders with the indigenous African populations that sub-Saharan Africa was made part of the intercontinental systems of the Atlantic and Indian Ocean.

Some historians have claimed that the term "Creole" should only be applied to the communities that were formed in the Cape Verde and Guinea Islands, where creole languages emerged, but this seems an unhelpfully restrictive definition, for creolization was not just an end product. It was a complex process of cultural interaction and change that could transform the lives of individuals and elite groups as well as slaves and their descendants (Seibert, 2012, p. 29-51).

Creolization, sometimes referred to as "transculturation", is essentially a dialectical process that occurs when different cultures come into contact (Naro, Sansi-Roca and Treece, 2007 , p. 44). There is a spectrum of creolization. At one end there is limited cultural interactions like the incorporation of loan words and the adoption of material goods from another 
culture. At the other end is a more or less complete adoption of a new culture and language with the retention of only vestiges of an original way of life.

\section{Island Creole communities}

The initial settlements resulting from Portuguese overseas expansion were made on the Atlantic Islands and the system of captaincies established by the Crown ensured that, from the start, these island communities enjoyed a high degree of autonomy that was facilitated by their distance from Portugal and relative proximity to Africa, and by the emergence of a distinct creole culture.

The creole society that was formed drew cultural elements from Portuguese, Jewish and African sources and was characterised in the Cape Verde and Guinea Islands by the emergence of a free black population, by distinct creole dialects of the Portuguese language and syncretic forms of religious practice. Madeira and the Azores retained a more European cultural orientation (although distinct in many ways from mainland Portugal), but in the Cape Verde and Guinea Islands, African cultural traits predominated-notable among them the prominent role played by women in the family and commercial life of the islands (Green, 2012; Havik, 2015, p. 30-48; Santos, 1991-2002).

The beginning of the Atlantic phase of globalisation in the mid-fifteenth century witnessed three broad population movements. As Christian Portuguese and Castilians left their motherlands to seek their fortunes overseas, they were joined by Jews and New Christians exiled by the religious policies of the Crown and by increasing numbers of black slaves.

Creolization can be seen at work in the partial absorption of African slaves and Jews into the population of Portugal itself and in the emergence of a free black "creole" population in the Cape Verde and Guinea Islands. In Maria Emilia Madeira Santos's words

[...] the distance of the central power and its lack of supervision over institutions facilitated a certain liberality in customs, the black family existing in parallel with the legitimate family, luxurious dress and the immoderate consumption of food contrary to the legislation in force. Children legitimate or not were acknowledged and shared the space with Europeans. ${ }^{3}$

All the islands established close commercial links with Africa and by the end of the fifteenth century had begun to set up trading posts on the African coast. During the sixteenth century creole communities originating in the islands took root at various points on the African mainland-notably along the coast from Senegal to Sierra Leone and in the

3“A distância do poder central e da tutela das instituições facilitava a largueza de costumes, a família negra paralela à família legítima, o vestuário faustoso, alimentação desregrada contrariando a legislação vigente. Os filhos legitimados ou não eram aceites e partilhavam o espaço dos europeus" (Santos, 2006, p. 55-64). 
region south of the Zaire river, including the island of Luanda. On the mainland of Africa island creoles, often called lançados, married into free African lineages, traded within the rules of long established commercial networks, and gave birth (both literally and metaphorically) to the Black Portuguese who formed a class of brokers along the whole coast from Senegal to the Niger delta. ${ }^{4}$ The lançados acquired slaves and attracted free clients (called grumetes) from surrounding populations. Studies of these trading communities have emphasised their cultural syncretism, especially in religious matters, their systems of dual loyalty and the development of a Portuguese-based trading language. Whereas Portuguese names were retained, European clothes worn, European luxuries imported and a characteristic style of house building developed (Mark, 2002), there was no introduction of European technology and the Black Portuguese adopted African modes of production and commercial organisation.

However, the Black Portuguese differed in one crucial respect from the other merchant groups trading in Africa. The Cape Verde and Guinea Islands were creole polities which were wholly independent of the control of any African ruler and largely independent of Portugal as well. These creole polities not only offered a base from which coastal traders could draw supplies, raise capital and find maritime transport, but they came to play a political role in the affairs of mainland Africa. Fugitives from wars on the mainland were sometimes able to take refuge in the Cape Verde Islands and Cape Verde islanders in turn could escape to the mainland from the effects of drought and the deteriorating environmental conditions. Meanwhile São Tomé, where a prosperous plantation system emerged producing sugar for an international market, also became a base for trade with the African societies of the Bight of Benin and for interventions in the Kongo kingdom.

Toby Green has argued that during the course of the sixteenth century the creoles had a profound effect on the lives of the mainland populations - the slave trade leading to increased violence which in its turn led Africans to adopt protective measures, while the trade in foodstuffs, essential for the slave trade, "extracted the agricultural surpluses" of the African populations - perhaps a rather one sided way of looking at the profit and loss account of increased agricultural production (Green, 2012, p. 108).

Although creoles of mixed descent were widely accepted within the Portuguese community, some Portuguese institutions were slow to accept the process of creolization. André Álvares de Almada, the distinguished author of the Tratado Breve dos Rios de Guine do Cabo Verde, became a knight of the Order of Christ although he was of mixed parentage "and it was rare for the habit of the Order of Christ to be bestowed on mulattoes since its members had to demonstrate their "purity of blood". 5

${ }^{4}$ For an up to date discussion see Green (2012).

5“E era raro o hábito de Cristo ser concedido a mulatos, para tal tinha que ser provada 'pureza' de 'sangue”" (Horta, 2011, p. 85). See also Silva (2011). 


\section{Creole polities in the mainland}

In contrast to what happened in the upper Guinea region, in Angola the creoles created their own mainland state. Angola was established as a captaincy in 1575 where, unlike the situation in Guinea, the Portuguese used military force to conquer extensive territory for themselves. By the early seventeenth century the Portuguese had established a kingdom, based on Luanda and the Cuanza valley, with a large subject population. The Portuguese population of this state was made up of indigenous Africans, immigrants from Portugal (mostly soldiers, criminals, exiles and prostitutes) and Brazilians, including some Brazilian Indians. As Marianna Candido has emphasised the creolization process in Angola effected not only Africans and people of mixed race but also the Portuguese and Brazilians who came to Africa. This new Angolan polity, which in 1617 extended its reach south to Benguela from where it could penetrate the southern highlands, soon became not only a major military power in the region, reducing many African societies to client status, but became the most important base for the expanding commerce with the Atlantic world. Through the creole controlled ports of Angola imports from Europe, India and the Americas were taken by creole pombeiros to inland fairs where they were exchanged for slaves. The importance of this trade attracted a wide range of African participants and opened trade routes deep into the interior. It helped to determine the evolution of the kingdoms in the interior whose social and economic structure became organised to serve the Atlantic trade (Candido, 2013, p. 139).

The elites of some African societies in the region adopted aspects of creole culture, importing European weapons and consumer goods and even adopting Christianity, European dress and European names. The adoption of Christianity as an official cult by the Kongolese rulers and aristocracy opened the way for the entry into the kingdom of large numbers of Portuguese and creoles who became influential in trade, religion and politics. Although the Portuguese never controlled the kingdom, creole culture penetrated all aspects of Kongolese life, and the economic activity of the kingdom and its trading partners in the interior and north of the Zaire river became oriented towards the Atlantic with the supply of slaves the dominant form of commercial activity. ${ }^{6}$

If the most striking example of this partial creolization was in the kingdom of Kongo, there were also examples among the minor rulers of Guinea and in Angola where, for example, queen Njinga, famous for her resistance to the Portuguese, was a baptised Christian and had a Portuguese as well as an African name. ${ }^{7}$

${ }^{6}$ For the the Kongo kingdom see Heywood and Thornton (2007) and Hilton (1985). For another example see Pinto (2015, p. 432-434).

${ }^{7}$ Heywood and Thornton (2007). In particular chapter 4 "Atlantic Creole culture". 
Atlantic trade profoundly affected African societies, but in diverse ways-imported firearms and horses influenced warfare, state formation and the acquisition of slaves for export; the bronze casters of Benin and the ivory carvers of Sierre Leone responded artistically to new ideas and new markets, while traditional honey-hunters turned to the large scale production of beeswax for the Atlantic market (Mark, 2014, p. 236-266; Gemery and Hogendorn, 1978, p. 243-258; Tuck, no d., p. 285-303). New World food crops were widely adopted in Africa, contributing to population growth, which to some extent mitigated the losses due to the slave trade. In Central Angola "daily activities and the lifestyle of populations located far from the coast changed, reflecting the widespread consumption of imported goods" (Candido, 2013, p. 190). Yet creolisation did not result in any significant transfer of technology. The wheel-based technologies of contemporary Europe were not adopted, possibly due to the importance African elites attached to wealth in people, including slaves, which tended to prevent, or delay, the adoption of new technologies. As a result the economic gap between Africa and the rest of the world inexorably widened (for example, Law, 1980, p. 249-262).

\section{Trans-Atlantic trade}

The most important innovation that the Portuguese creole traders brought to Africa was the commercial links with the New World which opened up vast new markets for exported African produce and labour, and led to the introduction of American food crops into Africa. The creole communities in the islands were of fundamental importance in determining how the initial contacts with the New World developed. Seamen from the Azores had explored the western Oceans, and the Azores and later the Cape Verde Islands became regular stopping places for ships plying between Europe and the Americas. The earliest settlements on the coast of Brazil followed a pattern already familiar in Africa. Traders, many of them New Christians, made camps on the coast to collect dyewood and formed relations with Indian women which led to the emergence of a creole population in which the culture and way of life of the Indians was the predominant feature. The system of captaincies, which had been used in the settlement of the islands, was introduced and gave the settlements in Brazil the same degree of autonomy enjoyed by the creole islands. Towards the end of the century it was sugar growers from the island of São Tomé who moved to Brazil and promoted the development of the sugar industry in the northern coastal districts.

The sixteenth century, therefore, saw an extension of the autonomous creole commercial world across the Atlantic linking Africa, not just commercially but culturally and institutionally, to the emerging societies in America. 


\section{The slave trade}

Portuguese creoles did not initiate the slave trade from Africa, as slaves had been traded across the Sahara for centuries and Europeans had raided the Canary Islands and taken Muslim slaves from north Africa. North Africans for their part raided European coastal communities for slaves or captured Christian slaves at sea. In the fifteenth century ships from Portugal had made the long journey to Senegambia to bring back slaves for sale in Europe - one estimate being that 50,000 slaves were imported into Europe from West Africa in the fifteenth century.

The beginning of the trans-Atlantic slave trade, however, was a new departure and was pioneered by the creole islanders. Customs documents from Cape Verde show the regular arrival of boats carrying small consignments of slaves from western Africa. Many of these slaves were integrated into the population of the islands and in Madeira and São Tomé they were employed on the sugar plantations. After the first two decades of the sixteenth century, however, many were sold on to various markets in the Americas (Hall, 2015).

The forced migration of labourers from Africa to Europe, the Atlantic Islands and the Americas was only one aspect of the population movements which characterised the early modern world. It has to be seen alongside the emigration of Portuguese and Castilians from the Iberian peninsula and the diaspora of the Sephardic Jews both of which became inextricably mixed with it. As migrants left Portugal to settle the islands, to travel East to the Estado da India and to settle in Brazil and Spanish America, Africans arrived in Portugal to fill gaps in the labour force and joined Portuguese and New Christians in the peopling of the islands and the New World.

The very approximate guesswork that has to take the place of real statistics suggests that between 1400 and 1640 perhaps as many as 700,000 people left Portugal and rather fewer left Spain. 70,000 Jews and people of Jewish origin left the Iberian peninsula as a result of the 1492 decrees with a steady stream of departures thereafter. Meanwhile the Slave Voyages Database suggests 277,405 slaves being exported during the sixteenth century with three times that figure in the following fifty years. Although clearly the numbers of slaves came to exceed the "free" emigration of Portuguese and Spanish, it is important to see the slave trade in the context of a diverse and unprecedented movement of population within the Atlantic basin which provided the ingredients for the creolization that took place. ${ }^{8}$

Slaves brought from Africa often spent some time in the islands before being bought and shipped onwards to the New World. The whole process is vividly described in the account Francesco Carletti wrote of his voyage round the world which began in 1594 where he says "the Portuguese keep [the slaves] in their villas in the country in herds like cattle" (Carletti,

8These figures are discussed in Newitt (2015) and sources quoted. 
1965). Being kept in the islands ensured that a certain amount of creolization would take place before the captives were shipped to the New World.

The development of the Portuguese creole trading network in Angola after 1575 fed the great expansion in demand for labour from the growing sugar economy of Brazil and later the gold mining in the interior. Over one million slaves were sent to Brazil between 1575 and 1700 and a further million in the first half of the eighteenth century. The slaves joined a society that was already substantially creolized through mixture with the native Indian population and themselves underwent a rapid process of creolization. In spite of a marked rise in racial consciousness among European Portuguese in the sixteenth century, the black population of Brazil never formed a caste in society separate from the creole population or even from the whites of direct European extraction.

In Brazil, Angola and the islands some Africans, uprooted from their own societies by the slave trade, combined to form independent maroon communities, another form of African creolization. In Brazil the history of Palmares is well known and some quilombo communities have survived into the twenty-first century. Less well known are the maroon communities that are recorded as early as the sixteenth century in the islands. In São Tomé, the Angolares remain a distinct social group with their own language to the present, and in Cape Verde the so-called Rabelados remain a separate and distinct African creole group in the island of Santiago. ${ }^{9}$

The arrival of new African slaves continued to inject African cultural elements into Brazilian life and their numbers outstripped direct immigration from Europe until the second half of the nineteenth century when the slave trade ceased and the place of slaves was taken by poor white immigrants. At least two million European immigrants arrived by the end of the century, and in many parts of Brazil replaced people of African heritage and native born Brazilians in the labour force.

\section{Creolisation in the New World}

Creolization of great complexity took place among the slave populations sent to the New World and in the Spanish America attempts were made to formalise the complexities of creolisation as can be seen in the series of Casta paintings which were produced in the eighteenth century. ${ }^{10}$ Slavery and the slave trade has, understandably, usually been seen as a process which dehumanised captives, turning them into chattels and denying them human rights. But slaves resisted that dehumanisation, often through adroit forms of cultural appropriation and synthesis that resulted in remarkable examples of creolization. Many slaves came

${ }^{9}$ See Seibert (2015, p. 82-101). In Spanish America they are known as palenques. See McKnight (2009, p. 64-81).

${ }^{10} \mathrm{~A}$ rare, and seldom seen, set of Casta paintings can be found in Braemore House in Hampshire UK. 
from communities already partly creolized and knew that, to survive, they had to adopt the patois of the new society, and adjust to its religious beliefs and material culture. Racial mixing and manumission led to the growth of free black populations, more integrated into the prevailing creole culture than the newly arriving slaves who strove to retain elements of the languages, religions and cultural practices of Africa. In Brazil the partial absorption of the Amerindian populations added further ingredients to the mix.."

If it was creole merchants from the islands who introduced sugar growing to Brazil and organised the mass (forced) migration of Africans to the New World, the tide of creolization soon flowed back to Africa through many different circuits-Brazilian food crops, like maize, manioc and peanuts, spread in Africa, Brazilians were appointed as governors of Angola, Brazilian soldiers, including Amerindians, fought in African wars, Brazilian merchants traded tobacco for slaves and even settled in the West African ports and Brazilians brought the cacao tree to São Tomé and set in motion the great boom in West African cocoa production. ${ }^{12}$ Creolization, therefore, was not a uniform or one-way process limited to a few island communities, but the natural and organic cultural change, affecting whole continents, that was inseparable from the growth of a global economy.

The Portuguese embrace of creolization contributed to a demographic dynamism lacking in the British colonies. In the seventeenth and eighteenth centuries Britain struggled to establish communities in the New World: emigration rates were low and racial segregation prevented the emergence of a dynamic creole population. This is in marked contrast to the Lusophone areas of the Atlantic where strong Portuguese creole communities were established and, as Nancy Naro (2007, p. 131) has written, "the breadth of Portugal's multicultural empire attested to centuries of cultural pluralism, integration and unity under a sovereign head of state". By 1800 the population of Brazil was approximately twice that of the thirteen colonies, which formed the United States. One highly visible consequence of this was the rapid territorial expansion of Brazil beyond the Tordesillas Line compared with the British North American colonies, which were still largely confined to the eastern seaboard (Burnard, 2012, p. 407-432).

\section{East Africa}

The scholarly debate over creolization and the history of the slave trade has concentrated almost exclusively on West Africa and the Atlantic world, but there is also a story to tell about eastern Africa, though one that is in many respects different. ${ }^{13}$

"There is a big literature on this topic. See for example, Sweet (2003) and Russell-Wood (2015). For the role of black sailors see Rodrigues (2012, p. 175-190).

${ }^{12}$ Atlantic influences were passed along trade routes from one part of Africa to another, as emphasised by Mann (2001).

${ }^{13}$ In some scholarly work Mozambique is included within the concept of a Lusophone Black Atlantic because of the importance of the slave trade from eastern Africa to Brazil. See Naro (2007, p. 129). 
Eastern Africa was part of the Indian Ocean world, which for centuries had formed a distinct economic and cultural contact zone, held together by the seasonal monsoons. These commercial and cultural contacts led to the formation of creoliszd communities of Muslim ship-owners and merchants who operated in a number of different cultural environments, much as their counterparts in the trans-Sahara trade of West Africa were doing. In eastern Africa the cultural mixing that resulted was evident in the Islamised coastal cities and in the emergence of Swahili which was a creole language. There were even "creole islands", which resembled the creole islands of the Atlantic-for example Zanzibar and the Comoros group inhabited by merchant elites who claimed ancestry from lineages in the Gulf and who imported, and mixed with, slaves from Africa. ${ }^{14}$

When the Portuguese arrived they found well-established commercial networks stretching to India, the Gulf, and further East towards China. Similar networks had existed in western Africa where Muslim trade had extended overland towards the Mediterranean. The Portuguese had not competed with these but had pioneered wholly new maritime trade routes to both Europe and the Americas, which they monopolised for the best part of a century. In the Indian Ocean, however, the maritime trade routes, developed by Muslim merchants, already existed.

As a result the Portuguese initially tried to elbow their way into the existing system and impose trade monopolies by force. However, they did not possess the military or naval capacity to control three thousand miles of coast and individual Portuguese who wanted to trade with the established African and Islamic communities in eastern Africa found they had to work within existing trading networks. These men resembled the lançados of western Africa, marrying into local lineages and adopting the prevailing commercial and cultural practices. Some settled at the inland trading fairs and developed an elaborate relationship with the surrounding African polities. In western Africa this kind of relationship had been the traditional one of landlord and stranger. In eastern Africa the Portuguese were adopted as symbolic wives of the rulers, a privileged status that was sealed with periodic gifts which nonetheless signalled a subordinate position.

Only south of the monsoon belt were the Portuguese substantial innovators, bringing Delagoa Bay and the southern regions that now form Swaziland and South Africa into the Indian Ocean trading system for the first time. The Portuguese also forged links between the Indian Ocean and the Atlantic which hitherto had not existed. The Indian Ocean and Atlantic commercial systems are often treated separately in the scholarly literature but the regular passage of Portuguese Indiamen through the Atlantic meant that the Indian Ocean and Atlantic commercial systems became closely interlinked. Portuguese Indiamen routinely stopped at Brazilian ports, while copper obtained in Angola was sent to India for

14There is a large literature on this topic. See Pearson (1998). 
the purchase of spices (Candido, 2013, p. 36 and 47). Indian textiles were brought to West Africa in the early sixteenth century and their motifs were copied by Sape ivory carvers; so important was this exchange that the export of slaves from Angola became dependant on the supply of Indian textiles from the Estado da India. Cowries from the Maldives were also traded in the markets of western Africa.

The slave trade also linked the Atlantic and the Indian Ocean, and during the Dutch occupation of Luanda and São Tomé in the 1640s, Brazilian slavers bought slaves in eastern Africa. Brazilians became more prominent in the East African slave trade in the eighteenth century and in the early nineteenth century the squeeze on the slave trade in western Africa diverted the activities of other Atlantic slavers to East Africa. Large numbers of Cuban and Brazilian ships appeared in east African ports and Brazilians were increasingly to be found among the creole population of eastern Africa - an example being Albino Manuel Pacheco who came to east Africa employed by a Brazilian slaving syndicate, settled there and became an important figure in the expansion of Portuguese influence up the Zambesi, writing a detailed account of his journey in 1861. Whalers, mostly from the United States but often with Cape Verdian or Azorean crews, were also frequent visitors and, after the Portuguese formally abolished the slave trade in 1842 , Brazilian slavers often tried to pass as whalers when stopped by anti-slave trade cruisers (Curto and Soulodre-La France, 2004; Newitt, 2013).

In the course of the seventeenth century Portuguese creoles had acquired large tracts of land south of the Zambesi and on the Zimbabwean plateau. This territory became a Portuguese dominion larger than the land controlled from Luanda and greater in size than the kingdom of Portugal itself. It was divided into prazos-feudal holdings whose rulers obtained titles from the Portuguese crown but who ruled their domains like traditional African kings.

As in western Africa, the creole community was made up of an elite of merchants and prazo senhors of Portuguese, Indian or mixed racial origin, and Africans who attached themselves as clients. In western Africa these clients were known as grumetes, in eastern Africa they were called chicunda and came to acquire a distinct ethnic identity. In East as in West Africa the urban environment of trading towns was where new identities were often formed. The creole population and their chicunda followers were at least nominally Christian, though religious syncretism meant that spirit mediums were found to speak with the voice of dead senhors and some of the Dominican missionaries themselves assumed the prevalent creole culture, with large followings of African clients and numerous African wives (Newitt, 2010, p. 67-92; 2013).

In one important respect, however, this creole society, differed from that in western Africa. Large numbers of Indians, many of them Christian Canarins from Goa, crossed to east Africa to trade under Portuguese auspices. They made a significant contribution to the cultural mix that formed the east African creole community. Creoles of Indian origin not 
only controlled many of the prazos but took the lead in founding the new trading settlements of Zumbo and Inhambane in the eighteenth century, and in opening the way for Indian merchant capital which, for most of the eighteenth century, dominated the ivory trade (Machado, 2001, p. 254-280).

The "indianisation" of the Portuguese settlements in eastern Africa and the growing Indian element in the creole population can be compared with the growing influence of Brazilians in western Africa, the Portuguese connection providing the matrix within which new trans-oceanic linkages and new creole identities were made.

Portuguese trade in the Indian Ocean was more diversified than that in the south Atlantic and, until the last quarter of the eighteenth century, gold and ivory were far more important than slaves in the general mix of commerce. The characteristics of this trade encouraged creolization. Most of the gold was obtained by professional traders at fairs where Portuguese, creole and African merchants had to find ways of doing business with each other. In the eighteenth century the most important gold fair was at Zumbo, which was granted the status of a town, its creole merchants becoming town councillors and briefly enjoying great prosperity. ${ }^{15}$ Ivory, on the other hand, was brought by caravans to the coast where it was purchased by Portuguese agents who operated through the local networks. In the nineteenth century these creole agents themselves began to organise ivory hunting expeditions, which spearheaded Portuguese penetration into the interior.

In the last quarter of the eighteenth century there was a significant rise in the slave trade, initially associated with the expansion of French plantations in the previously uninhabited Mascarene and Seychelles islands. Later slave traders from Brazil and the United States began to buy large numbers of slaves as the ports of western Africa became gradually closed to them. The slave trade became an important factor in the militarization of east African society, as Portuguese and Muslim creoles built up armies to fight each other and to expand their influence in the interior. By the middle of the nineteenth century creole warlords, slavers and ivory hunters were operating deep in the interior. Contact was even made between the creole communities of West and East Africa, stretching their networks of influence from one side of the continent to the other (Newitt, 1995).

The Portuguese presence in eastern Africa became as dependent on the creole elites, many with Indian origins and Indian connections, as it did in Angola and Guine. The private armies maintained by the creoles supported Portugal's military campaigns and raised the Portuguese flag over newly occupied territory. In Zambesia the creole community continued to be largely autonomous, defying Portugal's attempts to suppress the slave trade and, in the so-called Zambesi Wars, mounting determined opposition to tighter Portuguese control. On the other hand, it was the expansion of creole influence inland that enabled

${ }^{15}$ See Newitt (2013) and especially the publications of S. I. Mudenge discussed therein. 
Portugal to claim the substantial territory that came to form Mozambique just as the region where creole traders had been active in western Africa enabled Portugal to establish its claims to Angola.

However, creole influence in eastern Africa followed a different path from that in Angola. In western Africa creole influence was strong in the Angolan cites of Luanda and Benguela and their immediate hinterlands, was entrenched in the Atlantic Islands and in Brazil where many African creoles owned property, sent their children to be educated and went themselves for medical treatment. In eastern Africa there was no equivalent to the creole metropolis of Luanda. Mozambique Island, as the centre of Portuguese creole influence, was some two hundred miles from the centres of creole power in the Zambesi prazos and, although Mozambique Island developed its own creole culture, this was on a scale much smaller than that of Luanda or Benguela. Then, in the final years of the nineteenth century the capital was relocated to Delagoa Bay in the extreme south where the influence of South Africa was dominant, and which was even further from the creole heartland. The creoles of Zambesia found themselves marginalised-Zambesia suffering war, rebellion and invasion and finally coming under the control of plantation companies, mostly British owned, where the creoles had little influence. In the capital an educated creole class continued to exist, voicing its opposition to colonial policies during the comparative freedom of the Republic but this class was small and had few roots in the local population.

Although large numbers of African slaves were exported to destinations in the Indian Ocean and Asia, they never formed a significant proportion of the populations as they did in the Atlantic. Even in the Mascarene Islands, the creole cultures that developed were soon swamped by the arrival of Indian contract workers, while the Africans brought by the Portuguese to Sri Lanka never formed more than a small, if colourful, minority in the population (Jayasuriya, 2003, p. 25l-288).

\section{Creole culture}

By the early nineteenth century Portuguese creole communities predominated in eastern Africa, and on both sides of the southern Atlantic. In the areas of formal Portuguese settlement in Africa, creoles made up the administrative class and the personnel of the armed forces. They owned the land and the trading ships, formed the merchant and broker classes, became town councillors and brothers in the Misericórdia. Creoles also constituted a large part of the priesthood of the Catholic church (Candido, 2013, p. 114-115 and 124-125).

Throughout the world Portuguese Creoles-Europeans who had settled in Africa and adopted African customs, those of mixed race and indigenous people who had adopted Portuguese names, Portuguese customs or spoke a Portuguese creole language-were 
recognised members of Portugal's global community, their Portuguese-ness ultimately depending on their adherence to the Catholic faith and in some cases an expressed loyalty to the Crown. In many "Portuguese" diasporic communities, which survived outside Portuguese jurisdiction in Africa and Asia, the specifically Portuguese element in the creole culture was so diluted that it often amounted to little more than the use of Portuguese names, a nominal Catholicism and the wearing of hats. And yet these people often claimed affiliation with the Portuguese when it suited their needs. ${ }^{16}$

This diverse creole world was not in any sense a world of equality as it was universally slave-owning, but it was marked by a rich and creative mixture of cultures, which found expression in social customs, carnival, food, art, music, dance, religious observance, and in social relations where the role of women, not only as mothers but as property owners and brokers, often prevailed over the patriarchal presumptions of Portuguese law and custom (Havik, 2015; Candido, 2013, p. 268-269).

In 1933 Gilberto Freyre memorably described the Brazilian creole world before its values had been critically undermined by the all-pervading racist ideologies of the late nineteenth and early twentieth centuries (Freyre, 1946). In the second half of the nineteenth century the import of African slaves into Brazil had been replaced by the arrival of immigrants from Portugal and Italy. At the same time Britain's campaign against the slave trade merged with the European "scramble for Africa". In order to counter Portugal's claims to Central Africa the British systematically branded Portuguese creoles as slave traders, whose degenerate slaving propensities resulted from miscegenation. This narrative contributed, in turn, to the idea that the Portuguese were not really white Europeans and therefore not the heralds of progress, a prejudice that reverberated round the world. Portuguese immigrants in the British Caribbean, for example, were not accepted as Europeans but in census returns received a separate classification of their own (Newitt, 2015, p. 170-171).

To counter this threat to their imperial status, Portuguese politicians were quick to mimic the racial policies of the British and Americans (Williams, 2015, p. 127-141). To protect its overseas territories from their European rivals, Portugal had to be seen to be in the forefront of those bringing "civilisation" and "progress" to Africa. In pursuit of this policy, creoles became an embarrassment and in places such as Angola and Mozambique were replaced in public office by metropolitan Portuguese without the taint of African ancestry (Dias, 1984, p. 81-94). A strong strain of racism emerged in Portugal giving full expression to all the Manichean tendencies of twentieth century thought-setting black against white, civilised against uncivilised, indigena against assimilado. In many respects the period of Salazar's dominance witnessed racial policies almost as extreme as those in the British colonies (Henriques, 2012, p. 72-103). Almost, but not quite. Salazar, drawing on a longstanding

${ }^{16}$ See discussion in Newitt (2015) and sources quoted. 
Iberian imperial tradition, stretching back to Las Casas and the Dominican theologians, liked to extol the multiracial nature of the Portuguese colonies and recognised mestiços and a small minority of educated Africans as Portuguese citizens, a civilised status also granted to the creole populations of the islands, with Cape Verdians even being recruited into the colonial service. ${ }^{17}$

Nevertheless the deep contradictions between Salazarist ideology and colonial practice were never fully reconciled and it is no surprise that it was African creoles, marginalised by the racist policies of Portuguese imperialism, who became leaders of the nationalist opposition, elaborating their own ideology which rejected the importance of race and tribe and espoused a form of modernity which denied the binaries of race and civilisation embedded in the Salazarist project. The triumph of African nationalism in the 1975 independence agreements was the triumph not only of an elite of creole politicians but of a specifically creole ideology, silencing, or attempting to silence, a more "Africanist" strain of nationalism which found some expression in FNLA, UNITA and Renamo.

Este artigo foi apresentado no Colóquio Internacional África-Brasil: Ensino, Pesquisa e Relações Econômico-sócio-políticas, realizado pelo Programa de Pós-graduação em Relações Étnico-raciais do Cefet/RJ, em novembro de 2016, com o apoio da Capes, da Faperj e do Sesc Nacional.

17"The significant difference between Mozambique and its English-speaking neighbours, was that the principle of assimilation as an ultimate goal was never called into question" (Fry, 2007, p. 236). 


\section{Bibliographic references}

BURNARD, Trevor. Placing British settlement in the Americas in comparative perspective. In: BURNARD, H. V.; MANCKE, Elizabeth; REID, John G. Britain's Oceanic Empire: Atlantic and Indian Ocean worlds c.1550-1850. Cambridge: CUP, 2012. p. 407-432.

CANDIDO, Marianna. An African slaving port and the Atlantic world: Benguela and its hinterland. Cambridge: Cambridge University Press, 2013.

CARLETTI, Francesco. My voyage around the world. London: H. Weinstock, 1965.

CHABAL, Patrick; DALOZ, Jean-Pascal. Africa works: disorder as political instrument. Oxford: International African Institute/James Currey, 1999.

CURTO, José C.; SOULODRE-LA FRANCE, Renée. Africa and the Americas: interconnections during the slave trade. Trenton NJ: Africa World Press Inc., 2004. DIAS, Jill. Uma questão de identidade: respostas intelectuais às transformações económicas no seio da elite crioula da Angola Portuguesa entre 1870 e 1930. Revista Internacional de Estudos Africanos, n. 1, p. 81-94, 1984.

FREYRE, Gilberto. Casa-grande $\sim$ senzala. Translated as The masters and the slaves. New York: Alfred Knopf, 1946 [1933].

FRY, Peter. Undoing Brazil: hybridity versus multiculturalism. In: NARO, Nancy Priscilla; SANSI-ROCA, Roger; TREECE, David. Cultures of the Lusophone Black Atlantic. Basingstoke: Palgrave Macmillan, 2007.

GEMERY, H. A.; HOGENDORN, J. S. Technological change, slavery, and the slave trade. In: DEWEY, Clive; HOPKINS, A. G. The imperial impact: studies in the economic history of Africa and India. London: Athlone Press, 1978. p. 243-258.

GREEN, Toby. The rise of the trans-Atlantic slave trade in Western Africa 1300-1580. Cambridge: CUP, 2012.

HALL, Trevor P. Before the middle passage: translated Portuguese manuscripts of Atlantic slave trading from West Africa to Iberian territories, 1513-26. Farnham: Ashgate, 2015.

HAVIK, Philip. Mary and misogyny revisited: gendering the Afro-Atlantic connection. In: HAVIK, Philip J.; NEWITT, Malyn. Creole societies in the Portuguese colonial empires. Newcastle-upon-Tyne: Cambridge Scholars, 2015. p. 30-48.

HENRIQUES, Isabel Castro. Africans in Portuguese society: classification, ambiguities and colonial realities.
In: MORIER-GENOUD, Eric; CAHEN, Michel (Ed.). Imperial migrations: colonial communities and diaspora in the Portuguese world. Basingstoke: Palgrave Macmillan, 2012. p. 72-103.

HEYWOOD Linda; THORNTON, John. Central Africans, Atlantic creoles and the foundation of the Americas, 1585-1660. Cambridge: Cambridge University Press, 2007.

HILTON, Anne. The kingdom of Kongo. Oxford: Clarendon Press, 1985.

HOPKINS, A. G. (Ed.). Globalization in world history. London: Pimlico, 2002.

HORTA, José da Silva. A "Guiné do Cabo Verde". Lisbon: Fundação Calouste Gulbenkian, 2011.

JAYASURIYA, Shihan de Silva. The African diaspora in Sri Lanka. In: ; PANKHURST, Richard. The

African diaspora in the Indian ocean. Trenton NJ: Africa World Press, 2003. p. 251-288.

LAW, Robin. Wheeled transport in pre-colonial West Africa. Africa, n. 50, p. 249-262, 1980.

MACHADO, Pedro. Without scales and balances: Gujerati merchants in Mozambique c1680-1800. Portuguese Studies Review, n. 9, p. 254-280, 2001.

MANN, Kristin. Shifting paradigms in the study of the African diaspora and of Atlantic history and culture. In: __ B BAY, Edna (Ed.). Rethinking the African diaspora. London: Frank Cass, 2001.

MARK, Peter. "Portuguese style" and Luso-African identity. Bloomington: Indiana University Press, 2002.

African meanings and European-African discourse: iconography and semantics in seventeenth-century salt cellars from Serra Leoa. In: TRIVELLATO, Francesca; HALEVI, Leon; ANTUNES, Catia (Ed.). Religion and trade: cross-cultural exchanges in world history, 1000-1900. Oxford: OUP, 2014. p. 236-266.

MCKNIGHT, K. J. Elder, slave and soldier: Maroon voices from the Palenque de Limón, 1634. In:

GARAFALO, Leo. Afro-Latino voices: narratives from the early modern Ibero-Atlantic World, 1550-1812. Cambridge: Hackett, 2009. p. 64-81.

NARO, Nancy Priscilla. Colonial aspirations: connecting three points of the Portuguese Black Atlantic. In: ; SANSI-ROCA, Roger; TREECE, David. Cultures of the Lusophone Black Atlantic. Basingstoke: Palgrave Macmillan, 2007. 
; SANSI-ROCA, Roger; TREECE, David. Cultures of the Lusophone Black Atlantic. Basingstoke: Palgrave Macmillan, 2007.

NEWITT, Malyn. A history of Mozambique. London: Hurst, 1995. chap. 12-13.

Kinship, religion, language and political control: ethnic identity among the peoples of the Zambesi valley. In: KEESE, Alexander (Ed.). Ethnicity and the longterm perspective: the African experience. Bern: Peter Lang, 2010. p. 67-92.

(Ed.). Journey from Tete to Zumbo by Albino Manuel Pacheco. Oxford: OUP, 2013.

. Emigration and the sea. London: Hurst, 2015.

PEARSON, Michael. Port cities and intruders: the Swahili coast, India, and Portugal in the early modern era. Baltimore: Johns Hopkins University Press, 1998.

PINTO, Alberto Oliveira. História de Angola da pré-história ao início do século XXI. Lisbon: Mercado de Letras, 2015. p. 432-434.

RODRIGUES, Jaime. Mariners-slavers and slave ships in Atlantic, $18^{\text {th }}$ and $19^{\text {th }}$ centuries: the perspective of captives and the slaveholders logic. Africana Studia, n. 18, p. 175-190, 2012.

RUSSELL-WOOD, A. J. R. A world on the move. Manchester: Carcanet, 1992.

Atlantic bridge and Atlantic divide: Africans and Creoles in late colonial Brazil. In: HAVIK, Philip J.; NEWITT, Malyn (Ed.). Creolesocieties in thePortuguesecolonial empires. Newcastle-upon-Tyne: Cambridge Scholars, 2015.

SANTOS, Maria Emília Madeira. História geral de Cabo Verde. Lisbon: Centro de Estudos de História e Cartografia Antiga, 1991-2002. 3 v.
O primeiro centro urbano colonial nos trópicos: Ribeira Grande (Cabo Verde) séculos XV-XVII. Anais de História de além-mar, n. VII, p. 55-64, 2006. Quotation from 62.

SEIBERT, Gerhard. Creolization and Creole communities in the Portuguese Atlantic: São Tomé, Cape Verde, the rivers of Guinea and Central Africa in comparison. In: GREEN, Toby (Ed.). Brokers of change: Atlantic commerce and culture in precolonial West Africa. Oxford: OUP, 2012. p. 29-51.

Castaways, Autochthons. Or Maroons? The debate on the Angolares of São Tomé island. In: HAVIK, Philip J.; NEWITT, Malyn (Ed.). Creole societies in the Portuguese colonial empires. Newcastle-uponTyne: Cambridge Scholars Publishing, 2015. p. 82-101. [Originally published by Bristol University, 2007].

SILVA, Filipa Ribeiro da. Dutch and Portuguese in Western Africa. Leiden: Brill, 2011. chap. 3-4.

SWEET, James H. Recreating Africa: culture, kinship and religion in the Afro-Portuguese world 1441-1770. Chapel Hill: University of North Carolina Press, 2003.

TUCK, Michael W. Everyday commodities, the rivers of Guinea, and the Atlantic world; the beeswax export trade c.1450-c1800. In: GREEN, Toby (Ed.). Brokers of change: Atlantic commerce and culture in precolonial Western Africa. [no d.]. p. 285-303.

WILLIAMS, Rosa. Migration and miscegenation: maintaining boundaries of whiteness in the narratives of the Angolan colonial state 1875-1912. In: HAVIK, Philip J.; NEWITT, Malyn (Ed.). Creole societies in the Portuguese colonial empires. Newcastle-upon-Tyne: Cambridge Scholars, 2015. p. 127-141. 